to a north-north-westerly direction, the ship having drifted between these dates from $66^{\circ} 50^{\prime}$ to $73^{\circ} 20^{\prime}$ long. E.

No more powerful argument, we think, could be adduced than these facts for the establishment of a series of Arctic observatories; the influence of the changing Arctic conditions on the climate of Europe is unmistakable, and a knowledge of what these conditions are, and what laws they are subject to, would undoubtedly be of great practical value.

The chapter on the aurora is very interesting ; it contains the valuable observations by Lieut. Weyprecht, which we published in NATURE, vol. xi., p. 368 . Contrary to the experience of our own expedition and others in high latitudes on the American side, the auroras seen by the Tegetthoff were remarkably brilliant. No sound of any kind was observed to accompany the phenomenon.

Lieut. Payer's work, though professing to be only a popular narrative of the expedition, contains, it will be seen, much of great scientific interest, and we repeat that in the discussion of the results of our own expedition, his observations and conclusions will be found of real value.

\section{OUR INSECT FOES}

THE receipt of the eighth Annual Report on the 1 noxious, beneficial, and other insects of the State of Missouri, and the conferences on insect destruction in connection with the Paris Insect Exhibition recently held, bring again prominently forward the question-what are we to do to cope with our insect foes? Mr. Riley, the State entomologist for Missouri, in his report, gives account of five noxious insects-the Colorado Potatobeetle (Doryphora ro-lineata, Say), the Canker Worms (Paleacrita vernata) and (Anisopleryx pometaria), the genus Paleacrita being a new one; the Army Worm (Leucania unipuncta, Han.), the Rocky Mountain Locust (Caloptenus spretus, Tho.), and the Grape Phylloxera. In each case an account is given of the estimated amount of damage done, and the proposed methods for attacking the enemy, as well as the life history, so far as is lnnown, of the insect itself. While the damage by Colorado Beetle during 1875 was less than usual, owing to the excessive wet drowning the broods, and the Army Worm did comparatively little damage, the devastation caused by the locust was unusually heavy. Mr. Riley gives separately the accounts of different counties of the State.

One or two quotations will serve to indicate the gravity of the question, what is the remedy to be adopted? For example, in the account of Jackson County-" All kinds of growing crops disappeared before the black dead line of their advance. . . . With all the crops of wheat, rye, oats, flax, clover, corn, gardens, and pastures consumed in defiance of every human effort to stay the general devastation, the fields being as bare as the public roads, the outlook was gloomy beyond description. Many gave up in despair and left the county." So great was the destitution that relief meetings were held, the story of suffering being that many were reduced to a scanty supply of bread. Take again Buchanan County 'written June 7): "The crops are all destroyed now, together with meadows and pastures." Again, Bates County : "all our crops and pastures eaten off until they are as bare as in mid-winter." St. Clair County : "The terrible sights of the cruel war are now being outdone by the cruellest of sights-starvation." And so on with a large proportion of the counties. Some counties were so fortunate as to escape with small damage. The total loss to the State for the year is set down at $\$ 15,000,000$. A day of supplication to Almighty God, with fasting, was ordered on June 3 by the Governor. Mr. - Riley, however, repudiates the idea that this calamity was a divine visitation, and quotes from a speech he made in the previous May, in which. he said, "When I suggested last winter that a law should be passed offering a bounty for the eggs, the idea was ridiculed, but the people see now how wise such a course would have been. A few thousand dollars appropriated by the legislature for the purpose would have been the means of averting the present injury" (p. 93). The accounts given from some States describe the air as thick with locusts on the wing, so that darkness as of twilight was produced. We fortunately in England do not suffer from the locust, but we may learn a lesson as to what is the course considered necessary for coping with insect ravages. Nothing short of an Act of Congress to enforce the action to be taken seems to be regarded as of any real use. Although districts have previously suffered to the verge of starvation, we find Mr. Riley saying (p. 132), "It is very evident that if anything can be done at all in averting this evil, it must be done by nationa. means. The advantage of having the matter properly investigated by the national government has been repeatedly urged by many prominent persons in the west best competent to judge." Societies have recently passed resolutions, the resolutions have led to a memorial, and the memorial to the introduction of two bills into Congress. The one proposed the appointment of a commission of three by the Commissioner of Agriculture, who are to report on the best means of preventing incursions of the locusts. The other proposed that the Secretary of the Interior shall appoint a board of three entomologists on the nomination of the National Academy of Sciences. They were to report on noxious insects generally, and "as soon, also, as the information gathered shall enabl them, the commissioners shall compile practical instruc. tions for the suppression of the different insects referrec to." The amendments to both these bills were finally adopted in this form :- "That it shall be the duty of the Commissioner of Agriculture to investigate and gather information relative to those insects, \&c. ... and to make public from time to time such information and practical instructions for the suppression of the different insects." This, Mr. Riley remarks, is what people outside the senate were in the habit of supposing to be his duty. The chief practical suggestion Mr. Riley has to make is that State aid should be given for bounties of so many cents a bushel for the young insects while hatching. It will be some time, however, before we shall know what the Commissioner of Agriculture proposes to have done. Dr. Leconte, in his address before the American Association for the Advancement of Science at Detroit last year, urged the need for a law to compel farmers to destroy insects on their lands at a particular time.

Let us now turn to what has been done in France. We have already in a note, a few weeks ago, mentioned the way in which it is sought, through the elementary schools, to spread a knowledge of practical entomology. It remains now to refer to the attempts at legislation. As far back as 1732 a law was passed ordering farmers and landowners to destroy the caterpillars on their lands under a penalty of fifty livres. This 1732 law was renewed by prescriptions in 1777 and 1787 . During the revolution, fines were abolished and rewards for destruction were substituted. It was found this plan was of no practical use. In 1796 the law known as that of 26 Ventose, an. iv, was passed. It enacted that the destruction of caterpilliars should be effected by the owners or tenants of land, and that if they neglected to do it the adjoints were to have it down and recover the expense from the negligent owner or tenant. The public lands were to be done at public cost, and the Commissaires du Directoire Exécutif were to visit the districts to see that all been carried out. The penalty fixed was not less than three nor more than ten days labour, in addition to repaying the expenses incurred by the employment of workmen. This law, made in 1796 , is still the law for France, though practically it is not put in force. The local officials were found to hesitate in the performance 
of the duties laid down for them, those even who were disposed to carry them out saw how useless it was for one district to be cleared while adjoining districts remained as practically breeding grounds for the pests. That a workable law is wanted has been shown by the attempts in $1839,1849,1851$, and 1872 , to introduce a bill that shall repeal the old law and substitute one that could be worked. The first two attempts fell through in consequence of dissolutions, the coup d'état interfered with that of $185 \mathrm{r}$, but the proposal of 1872 was considered in March, 1873, passed a first reading December, 1874 , a second on January 5, 1875; while the amendments were under discussion, however, M. Ducuing, the proposer, died. Last May a projet dut loi, based on M. Ducuing's proposal, and somewhat modified in accordance with the discussion on the amendments, was introduced by MM. de la Sicotière, Grivart, and the Comte de Bouillé. They propose the law to apply to all harmful insects, the duty of destruction being imposed on the landowners and tenants. The time of the year to be selected for the destruction is to be made known by the prefect who will have scientific advice; the maires and commissionaires are to see that the law is carried out; in cases of neglect they are to have the work done, and recover the cost from those who should have done it. Special provisions are made for public lands, lands bordering on roads and railways. The fines are to range from Io to 25 francs for a first offence. The articles that refer to the protection of birds that eat insects are not applicable to the wants of England as we already have legislation on that subject. But for years the want of some definite action to cope with "our insert foes" has been over and over again the subject of articles, speeches, and letters to the public press. The experience of France and America is that farmers must be compelled to look to their own interests. The department of practical entomology under the direction of the Committee of Council on Education is designed to give information regarding England's insect pests, but the question remains-How is the knowledge to be applied for the practical goad of the country?

In connection witil this importane subject, the following extract from a Memorandum of the Canadian Minister of Agriculture, in reference to a despatch of the Secretary of State for the Colonies, on the subject of the Colorado Beetle is interesting :-

"The remedies which necessity has taught on this side of the Arlantic are such as to require for their application the joint effort of the community at large, kept alive to its interests and duties by the authorities, and men of devotedness to the common welfare. These remedies are (I) Searching for and crushing every potato-beetle whereever found; (2) Frequent visits to the potato-fields, and searching for the eggs deposited on the under-side of the leaves of the potato-vine; and (3) Watching for the presence of the larvæ on the buds and on the leaves of the plant, in order to destroy them by means of Paris green, the only substance yet discovered to be effectually operative on a large scale for the destruction of the insect in its larva state. By these means, and by these means only, the invaded American States, and the Western part of Canada, have been able to secure potato-crops in a measure commensurate with the care and energy bestowed, and by similar means only can the invasion be retarded and lessened in its effects. No measure has been taken in Canada, for reasons given, to prevent the falling or creeping of individual insects on board ships loading in Dominion seaports. There is, however, almost a certainty that the environs of Montreal will be invaded next year, and with that prospect in view, general orders may be given to public officers and employes of the ports to look for and destroy any beetles which might be observed on the wharves, on sheds, on pacliages of goods to be embarked, or on board ships. A general appeal might also be made to all persons having to deal with the shipping for assistance in the execution of such preventive measures. The undersigned respectfully recommends the adoption of such : precautions, beyond which he does not see that there is anything within the power of the Canadian Government to do."

\section{CARL $7 E L I N E K$}

R. CARL JELINEK was born at Brün, in Moravia, on October 23, 1822. He entered the University of Vienna in 1839 as a student of law, but soon thereafter his attention was turned more exclusively to the mathematical and physical sciences. In I843 he assisted in the work of the Vienna Observatory, and in I 847 was appointed assistant in the observatory of Prague. It was while assisting in the work of the Vienna Observatory, then under the direction of Kreil, that his interest in exact observations in the fields of meteorology and magnetism was awakened-an interest deep and strong, which soon merged in a life-sacrifice to the furtherance of these sciences.

It is not necessary here to dwell upon his connection with the events of 1848 further than to say that the high moral qualities for which he was in after life so remarkable were even then conspicuous, and that the knowledge he then acquired of men and affairs was an invaluable training for the successful discharge of the duties of the public offices he afterwards filled.

His first important contribution to science was a paper published in 1850 on the construction of self-registering meteorological instruments, an important department of practical science to which he continued to make contributions down to the last. Indeed the last published number of the Fournal of the Austrian Meteorological Society opens with the last of a series of articles by him on this subject. He was appointed in 1852 Professor of the higher mathematics in the Polytechnic School at Prague. Eleven years afterwards, or in 1863 , he returned to Vienna as successor to Kreil, the first director of the Central Institute for Meteorology and Magnetism at Vienna. In this new sphere his remarkable powers of administration and organisation had full scope. The influence of this calm, eager, untiring, and clear-sighted worker and administrator was immediately felt. A new spirit was infused into the machinery of the institute, its resources were increased, connections were formed on all sides with the similar institutes and societies of other countries, and its annual publications were enlarged and improved; and in the course of time not the least important change was effected by the erection of new buildings for the Meteorological Institute on the Hohe Warte -an open commanding position on the outskirts of Vienna-thoroughly equipped with all the instruments required for meteorological and magnetical observation of the most improved construction, and placed in positions which indicate a clear perception of the problems to be investigated and the methods by which the observational data for their solution might be obtained.

On June I4, I86., he was elected a corresponding, and on August 3, I866, a full member of the Imperial Academy of Sciences at Vienna. In 1864 he became a member of the Unterrichtsrath, and from 1870 to 1873 acted as secretary of the High Schools for technology and the schools for industry and commerce, and brought to bear on the discharge of these duties the matured results of science, a strong will, and an eagerness and activity that never flagged, which were productive of the best results to the interests of the department he served. His public services were recognised when he retired from the education department in 1873 , by having conferred on him the title and rank of Hofrath and the distinction of Knight of the order of the Iron Crown.

It is, however, in meteorology that he appears as an 